\title{
Ochrona danych osobowych i wizerunku ucznia w szkole - aspekty prawne
}

\begin{abstract}
Student personal data and image protection at school - legal aspects

The personal data of students are very important, and their protection from the point of view of the good of the child and the proper functioning of the institution is important. The main legal act that regulates it is the law on the protection of personal data. Teachers' awareness of the knowledge of the above-mentioned Act and its application and the consequences of its violations is important.
\end{abstract}

Key words: data, internet, school, director, administrator, student, parent, multimedia

\section{Wstęp}

Funkcjonowanie szkoły jest niemożliwe bez wykorzystania danych osobowych zarówno uczniów, jak i nauczycieli oraz rodziców (opiekunów prawnych), tym samym szkoły, jak i inne placówki oświatowe są zobowiązane do stosowania Ustawy $z$ dnia 29 sierpnia 1997 r. o ochronie danych osobowych ${ }^{1}$. Ponadto uczniowie, korzystając z Internetu, często nieświadomie udostępniają swoje dane osobowe

1 Ustawa z dnia 29 sierpnia 1997 r. o ochronie danych osobowych (Dz.U. z 2016 r., poz. 922 z późn. zmianami), Generalny Inspektor Danych Osobowych, Twoje dane-Twoja sprawa, Obowiązki dyrektora szkoły z zakresu ochrony danych osobowych, https://men.gov.pl/wp-content/ uploads/2017/04/poradnik-obowiazki-dyrektora-szkoly-z-zakresu-ochrony-danych-osobowych.pdf [dostęp: 25.01.2018]. 
i wizerunek różnym podmiotom. Szkoły mają swoje strony internetowe, jak i profile społecznościowe, gdzie umieszczają wizerunki uczniów, jak również ich dane osobowe. Celem artykułu jest zaprezentowanie regulacji prawnych odnoszących się do instytucji ochrony danych osobowych ucznia, jak i ochrony prawnej jego wizerunku. Autorka wskazuje obowiązki administratora danych osobowych w szkole, którym jest co do zasady dyrektor.

\section{Opis zagadnienia}

Szkoła, prowadząc strony internetowe, jak i profile na portalach społecznościowych, wykorzystuje możliwość promocji w Internecie. W literaturze jednocześnie zwraca się uwagę, że szkoła jest jedną z najbardziej konserwatywnych instytucji reagującą negatywnie na zmiany dokonujące się w obrębie nowych technologii które powinny mieć wpływ na kształt nowych instytucji edukacyjnych ${ }^{2}$. Niemniej zgodnie $\mathrm{z}$ art. 3 ust. 1 Ustawy $z$ dnia 29 sierpnia 1997 r. o ochronie danych osobowych ${ }^{3}$ ustawę stosuje się do organów państwowych, organów samorządu terytorialnego oraz do państwowych i komunalnych jednostek organizacyjnych, czyli również do szkół w rozumieniu Ustawy z dnia 7 września 1991 r. o systemie oświaty ${ }^{4}$. Należy podkreślić, że ustawodawca w art. 51 Konstytucji Rzeczypospolitej Polskiej zagwarantował prawo do ochrony danych osobowych. Zgodnie z przywołanym artykułem nikt nie może być obowiązany inaczej niż na podstawie ustawy do ujawniania informacji dotyczących jego osoby. Władze publiczne nie mogą pozyskiwać, gromadzić i udostępniać innych informacji o obywatelach niż niezbędne w demokratycznym państwie prawnym. Każdy ma prawo dostępu do dotyczących go urzędowych dokumentów i zbiorów danych. Ograniczenie tego prawa może określić ustawa. Każdy ma prawo do żądania sprostowania oraz usunięcia informacji nieprawdziwych, niepełnych lub zebranych w sposób sprzeczny z ustawą. Zasady i tryb gromadzenia oraz udostępniania informacji określa ustawa.

Pojęciem, które wymaga wyjaśnienia, jest pojęcie „dane osobowe”. W doktrynie wskazuje się, że prawo do ochrony danych osobowych jest również prawem trzeciej generacji, jeśli w ogóle występuje odrębnie od prawa do prywatności.

\footnotetext{
${ }^{2}$ M. Szpunar, Konektywizm - (r)rewoucja kształcenia w technologicznym świecie, „Horyzonty wychowania" 2015, s. 114.

${ }^{3}$ Ustawa z dnia 29 sierpnia 1997 r. o ochronie danych osobowych (Dz.U. z 2016 r., poz. 922 z późn. zmianami).

${ }^{4}$ Ustawa $z$ dnia 7 września 1991 r. o systemie oświaty (Dz.U. 2017 r., poz. 2198 z późn. zmiana$\mathrm{mi})$.

${ }^{5}$ Ustawa z dnia 2 kwietnia 1997 r. Konstytucja Rzeczypospolitej Polskiej (Dz. U. Nr 78, poz. 483 z późn. zmianami).
} 
Podkreśla się również, że odrębną regulację prawa do ochrony danych osobowych zawiera m.in. art. 13 ust. 2 konstytucji Szwajcarii (jako „prawo do ochrony przed nadużyciem jego danych osobowych”), art. 19 ust. 3 konstytucji Słowacji, art. 35 konstytucji Portugalii, art. 22 konstytucji Litwy, $\$ 3$ rozdziału 2 Aktu o formie rzqdu Szwecji z 28 lutego 1974 r. (w brzmieniu z 1988 r.) ${ }^{6}$.

Definicję danych osobowych wskazuje prawodawca w art. 6 Ustawy o ochronie danych osobowych, zgodnie $\mathrm{z}$ którym $\mathrm{w}$ rozumieniu ustawy za dane osobowe uważa się wszelkie informacje dotyczące zidentyfikowanej lub możliwej do zidentyfikowania osoby fizycznej. Osobą możliwą do zidentyfikowania jest osoba, której tożsamość można określić bezpośrednio lub pośrednio, w szczególności przez powołanie się na numer identyfikacyjny albo jeden lub kilka specyficznych czynników określających jej cechy fizyczne, fizjologiczne, umysłowe, ekonomiczne, kulturowe lub społeczne. Informacji nie uważa się za umożliwiającą określenie tożsamości osoby, jeżeli wymagałoby to nadmiernych kosztów, czasu lub działań.

W literaturze podkreśla się, że obecna definicja danych osobowych odpowiada definicji wskazanej w dyrektywie 95/46/WE7 . Należy podkreślić, że wskazana dyrektywa zostanie uchylona 25 maja 2018 r. Rozporządzeniem Parlamentu Europejskiego i Rady UE 2016/679 z dnia 27 kwietnia 2016 r. w sprawie ochrony osób fizycznych $w$ zwiazku $z$ przetwarzaniem danych osobowych i $w$ sprawie swobodnego przeplywu takich danych oraz uchylenia dyrektywy 95/46/WE (ogólne rozporządzenie o ochronie danych $)^{8}$. Zgodnie z pkt. 26. Rozporzadzenia zasady ochrony danych powinny mieć zastosowanie do wszelkich informacji o zidentyfikowanych lub możliwych do zidentyfikowania osobach fizycznych. Spseudonimizowane dane osobowe, które przy użyciu dodatkowych informacji można przypisać osobie fizycznej, należy uznać za informacje o możliwej do zidentyfikowania osobie fizycznej. Aby stwierdzić, czy dana osoba fizyczna jest możliwa do zidentyfikowania, należy wziąć pod uwagę wszelkie rozsądnie prawdopodobne sposoby ( $w$ tym wyodrębnienie wpisów dotyczących tej samej osoby), w stosunku do których istnieje uzasadnione prawdopodobieństwo, iż zostaną wykorzystane przez administratora lub inną osobę w celu bezpośredniego lub pośredniego zidentyfikowania osoby fizycznej.

${ }^{6}$ L. Garlicki, M. Zubik, Konstytucja Rzeczypospolitej Polskiej. Komentarz, t. II, wyd. II, Warszawa 2016, komentarz do art. 51, Lex.

7 Dyrektywa 95/46/WE Parlamentu Europejskiego i Rady z dnia 24 października 1995 r. (Dz.U.UE.L.1995.281.31); J. Barta, P. Fajgielski, R. Markiewicz, Ochrona danych osobowych. Komentarz, wyd. VI, komentarz do art. 6, Lex.

${ }^{8}$ Rozporzadzenie Parlamentu Europejskiego i Rady UE 2016/679 z dnia 27 kwietnia 2016 r. w sprawie ochrony osób fizycznych $w$ zwiąku $z$ przetwarzaniem danych osobowych $i$ w sprawie swobodnego przeplywu takich danych oraz uchylenia dyrektywny 95/46/WE (ogólne rozporządzenie o ochronie danych) (Dz.U.UE.L.2016.119.1). 
By określić, czy dany sposób może być z uzasadnionym prawdopodobieństwem wykorzystany do zidentyfikowania danej osoby, należy wziąć pod uwagę wszelkie obiektywne czynniki, takie jak koszt i czas potrzebne do jej zidentyfikowania oraz uwzględnić technologię dostępną w momencie przetwarzania danych, jak i postęp technologiczny. Zasady ochrony danych nie powinny więc mieć zastosowania do informacji anonimowych, czyli informacji, które nie wiążą się ze zidentyfikowaną lub możliwą do zidentyfikowania osobą fizyczną, ani do danych osobowych zanonimizowanych w taki sposób, że osób, których dane dotyczą, w ogóle nie można zidentyfikować lub już nie można zidentyfikować. Niniejsze rozporządzenie nie dotyczy więc przetwarzania takich anonimowych informacji, $w$ tym przetwarzania do celów statystycznych lub naukowych.

Zgodnie z poglądem panującym w doktrynie można stanowczo stwierdzić, że „na gruncie nowego stanu prawnego nie budzi już wątpliwości, że danymi osobowymi są wszelkie informacje dotyczące zidentyfikowanej lub dającej się zidentyfikować osoby, a nie tylko takie informacje, które same służą identyfikacji. Sama pojedyncza informacja jako taka $\mathrm{z}$ reguły nie pozwala bowiem na określenie tożsamości osoby, której dotyczy (z wyjątkiem np. zdjęcia czy kodu genetycznego)"9.

Poza omawianymi danymi osobowymi ustawodawca wskazuje również dane wrażliwe nazywane danymi sensytywnymi ${ }^{10}$. Ustawodawca $\mathrm{w}$ art. 27 ust. 1 Ustawy o ochronie danych osobowych stwierdza, że zabrania się przetwarzania danych ujawniających pochodzenie rasowe lub etniczne, poglądy polityczne, przekonania religijne lub filozoficzne, przynależność wyznaniową, partyjną lub związkową, jak również danych o stanie zdrowia, kodzie genetycznym, nałogach lub życiu seksualnym oraz danych dotyczących skazań, orzeczeń o ukaraniu i mandatów karnych, a także innych orzeczeń wydanych w postępowaniu sądowym lub administracyjnym. Jednakże zgodnie z art. 27 ust. 2 Ustawy o ochronie danych osobowych prawodawca dopuszcza przetwarzanie danych, jeżeli:

1) osoba, której dane dotyczą, wyrazi na to zgodę na piśmie, chyba że chodzi o usunięcie dotyczących jej danych;

2) przepis szczególny innej ustawy zezwala na przetwarzanie takich danych bez zgody osoby, której dane dotyczą, i stwarza pełne gwarancje ich ochrony;

3) przetwarzanie takich danych jest niezbędne do ochrony żywotnych interesów osoby, której dane dotyczą, lub innej osoby, gdy osoba, której dane dotyczą, nie jest fizycznie lub prawnie zdolna do wyrażenia zgody, do czasu ustanowienia opiekuna prawnego lub kuratora;

${ }^{9}$ J. Barta, P. Fajgielski, R. Markiewicz, Ochrona danych osobowych. Komentarz, wyd. VI, komentarz do art. 6, Lex.

${ }_{10}$ Tamże, Komentarz do art. 6, Lex. 
4) jest to niezbędne do wykonania statutowych zadań kościołów i innych związków wyznaniowych, stowarzyszeń, fundacji lub innych niezarobkowych organizacji lub instytucji o celach politycznych, naukowych, religijnych, filozoficznych lub związkowych, pod warunkiem, że przetwarzanie danych dotyczy wyłącznie członków tych organizacji lub instytucji albo osób utrzymujących z nimi stałe kontakty w związku z ich działalnością i zapewnione są pełne gwarancje ochrony przetwarzanych danych;

5) przetwarzanie dotyczy danych, które są niezbędne do dochodzenia praw przed sądem;

6) przetwarzanie jest niezbędne do wykonania zadań administratora danych odnoszących się do zatrudnienia pracowników i innych osób, a zakres przetwarzanych danych jest określony w ustawie;

7) przetwarzanie jest prowadzone $\mathrm{w}$ celu ochrony stanu zdrowia, świadczenia usług medycznych lub leczenia pacjentów przez osoby trudniące się zawodowo leczeniem lub świadczeniem innych usług medycznych, zarządzania udzielaniem usług medycznych i są stworzone pełne gwarancje ochrony danych osobowych;

8) przetwarzanie dotyczy danych, które zostały podane do wiadomości publicznej przez osobę, której dane dotyczą;

9) jest to niezbędne do prowadzenia badań naukowych, w tym do przygotowania rozprawy wymaganej do uzyskania dyplomu ukończenia szkoły wyższej lub stopnia naukowego; publikowanie wyników badań naukowych nie może następować w sposób umożliwiający identyfikację osób, których dane zostały przetworzone;

10) przetwarzanie danych jest prowadzone przez stronę $w$ celu realizacji praw i obowiązków wynikających $\mathrm{z}$ orzeczenia wydanego w postępowaniu sądowym lub administracyjnym.

Powyższe wyliczanie ma charakter taksatywny i nie można go poszerzyć, chociażby wynikało to $\mathrm{z}$ obiektywnych przesłanek na przykład danych dotyczących adopcji ${ }^{11}$.

Następnym pojęciem wymagającym doprecyzowania jest pojęcie wizerunku. Zgodnie z art. 81 Ustawy $z$ dnia 4 lutego 1994 r. o prawie autorskim i prawach pokrewnych ${ }^{12}$ rozpowszechnianie wizerunku wymaga zezwolenia osoby na nim przedstawionej. W braku wyraźnego zastrzeżenia zezwolenie nie jest wymagane, jeżeli osoba ta otrzymała umówioną zapłatę za pozowanie. W literaturze podaje się, że wizerunek w sensie prawnoautorskim jest pojęciem węższym od jego

11 Tamże.

12 Ustawa z dnia 4 lutego 1994 r. o prawie autorskim i prawach pokrewnych (Dz.U. z 2017 r., poz. 880). 
powszechnego rozumienia. Potocznie pod terminem „wizerunek” rozumie się nie tylko wygląd osoby, lecz także rzeczy, budowli, zwierząt. Na gruncie prawa autorskiego pojęcie „wizerunek” jest odnoszone tylko do osób fizycznych. Natomiast wizerunek osób prawnych rozumie się jako synonim ich dobrego imienia, reno$\mathrm{my}^{13}$. W piśmiennictwie wskazuje się, że „Termin »wizerunek« użyty w art. 81 oznacza wytwór niematerialny, który za pomocą środków plastycznych przedstawia rozpoznawalną podobiznę danej osoby (lub danych osób). Wizerunek utrwalony może być przez malarski portret, rysunek, fotografię"14.

Warto podkreślić, że zgodnie z wyrokiem Sądu Apelacyjnego w Warszawie z dnia 1 stycznia 2009 r. w sprawie o sygnaturze I Aca 22/09 tylko zgoda upoważnia do wykorzystania - w tym publikacji, wizerunku osoby prywatnej. Zgoda daje podmiotowi, który ją uzyskał, na działanie tylko w tym zakresie, a nie dla innych celów, choćby te były społecznie doniosłe ${ }^{15}$.

Odnosząc powyższe rozważania na grunt szkoły, trzeba pamiętać, że zgodnie z art. 7 pkt 4 Ustawy o ochronie danych osobowych administratorem danych jest organ, jednostka organizacyjna, podmiot lub osoba, o których mowa w art. 3 Ustawy o ochronie danych osobowych, decydujące o celach i środkach przetwarzania danych osobowych. Taka sytuacja ma miejsce w szkole. Tym samym reprezentujący i kierujący nią dyrektor ma zapewnić zgodność z prawem przetwarzania danych osobowych w podległej mu placówce, jak również ponosi odpowiedzialność za działania osób, które są upoważnione do przetwarzania danych. Odpowiedzialność ta może mieć charakter dyscyplinarny, karny oraz cywilny ${ }^{16}$.

Generalny Inspektor Ochrony Danych Osobowych stwierdził, że wiedza dyrektorów szkół w zakresie regulacji prawnych odnoszących się do ochrony danych osobowych jest niewielka, a Ustawa o ochronie danych osobowych obowiązuje w każdej placówce oświatowej bez względu na miejsce jej położenia i bez względu na organ ją prowadzący ${ }^{17}$. Główne obowiązki nałożone na dyrektora szkoły określa art. 26 Ustawy o ochronie danych osobowych. Zgodnie ze wskazanym artykułem dyrektor jest zobowiązany, aby dane osób, których dotyczą, były przetwarzane zgodnie z prawem, zbierane dla oznaczonych, zgodnych z prawem celów

${ }_{13}$ D. Flisiak, Prawa autorskie i prawa pokrewne. Komentarz, Warszawaa 2015, komentarz do art. 81, Lex.

${ }_{14}$ J. Barta, R. Markiewicz, Ustawa o prawie autorskim i prawach pokrewnych. Komentarz, wyd. V, komentarz do art. 81, Lex.

15 Wyrok Sądu Apelacyjnego w Warszawie z dnia 1 stycznia 2009 r. w sprawie o sygnaturze I Aca 22/09, Lex nr 1680164.

${ }_{16}$ Generalny Inspektor Danych Osobowych, Twoje dane-Twoja sprawa, Obowiązki dyrektora szkoły z zakresu ochrony danych osobowych, https://men.gov.pl/wp-content/uploads/2017/04/poradnik-obowiazki-dyrektora-szkoly-z-zakresu-ochrony-danych-osobowych.pdf [dostęp: 25.01.2018].

${ }^{17}$ R. Wiewiórowski, „Głos Nauczycielski” 27.10.2010, nr 43, s. 9. 
i niepoddawane dalszemu przetwarzaniu niezgodnemu z tymi celami, merytorycznie poprawne i adekwatne $\mathrm{w}$ stosunku do celów, w jakich są przetwarzane. Ponadto dane muszą być przechowywane w postaci umożliwiającej identyfikację osób, których dotyczą, nie dłużej niż jest to niezbędne do osiągnięcia celu przetwarzania. Z powyższych rozważań wynika, że administratorem danych uczniów jest szkoła, którą reprezentuje dyrektor.

Należy zastanowić się nad przesłankami zgodności z prawem przetwarzania danych osobowych w szkole. Przetwarzanie danych zgodnie $\mathrm{z}$ art. 7 pkt 2 Ustawy o ochronie danych osobowych to jakiekolwiek operacje wykonywane na danych osobowych, takie jak zbieranie, utrwalanie, przechowywanie, opracowywanie, zmienianie, udostępnianie i usuwanie, a zwłaszcza te, które wykonuje się w systemach informatycznych. Jeśli chodzi o dane osobowe, które nie są szczególnie chronione, przetwarzanie ich może odbywać się na zasadzie art. 23 Ustawy o ochronie danych osobowych. Wymagana jest zatem zgoda osoby, której dane dotyczą. Przez zgodę należy rozumieć (zgodnie z art. 7 pkt 5 Ustawy o ochronie danych osobowych) oświadczenie woli, którego treścią jest zgoda na przetwarzanie danych osobowych tego, kto składa oświadczenie. Co istotne, zgoda nie może być domniemana lub dorozumiana $\mathrm{z}$ oświadczenia woli o innej treści i może być odwołana w każdym czasie. Przetwarzanie danych może się również odbywać, jeżeli jest to niezbędne dla zrealizowania uprawnienia lub spełnienia obowiązku wynikającego z przepisu prawa. Ponadto przetwarzanie danych jest możliwe, jeśli jest to konieczne do realizacji umowy, gdy osoba, której dane dotyczą, jest jej stroną, lub gdy jest to niezbędne do podjęcia działań przed zawarciem umowy na żądanie osoby, której dane dotyczą. Kolejną przesłanką przetwarzania danych może być sytuacja, w której jest to niezbędne do wykonania określonych prawem zadań realizowanych dla dobra publicznego oraz jeśli jest to niezbędne dla wypełnienia prawnie usprawiedliwionych celów realizowanych przez administratorów. Należy pamiętać, że wymienione przesłanki mają charakter autonomiczny i każda $\mathrm{z}$ nich może stanowić samodzielną podstawę do przetwarzania danych osobowych ${ }^{18}$.

Natomiast przetwarzanie danych wrażliwych jest co do zasady zabronione. Jednakże ustawodawca wskazuje w art. 27 Ustawy o ochronie danych osobowych wyjątki od powyższej zasady. W szkole przesłankami przetwarzania danych osobowych wrażliwych będzie zgoda osoby, której dane dotyczą, wyrażona na piśmie, chyba że chodzi o usunięcie dotyczących jej danych (art. 27 ust. 2 pkt 1 Ustawy o ochronie danych osobowych) oraz jeżeli przepis szczególny innej ustawy zezwala

${ }^{18}$ Generalny Inspektor Danych Osobowych, Twoje dane-Twoja sprawa, Obowiązki dyrektora szkoły z zakresu ochrony danych osobowych, https://men.gov.pl/wp-content/uploads/2017/04/poradnik-obowiazki-dyrektora-szkoly-z-zakresu-ochrony-danych-osobowych.pdf [dostęp: 25.01.2018]. 
na przetwarzanie takich danych bez zgody osoby, której dane dotyczą, i stwarza pełne gwarancje ich ochrony (art. 27 ust. 2 pkt 2 Ustawy o ochronie danych osobowych).

Należy również wskazać przepisy szczególne, na podstawie których dyrektor szkoły jest upoważniony do przetwarzania danych osobowych uczniów, nauczycieli, jak i rodziców (opiekunów prawnych). Na początku należy wymienić wskazaną już wcześniej Ustawę o systemie oświaty ${ }^{19}$, Ustawę o systemie informacji oświatowej $^{20}$ oraz ustawę Karta Nauczyciela ${ }^{21}$, a także akty wykonawcze wydane na ich podstawie.

Należy podkreślić, że w szkole może dojść do sytuacji, kiedy przetwarzanie danych osobowych uczniów będzie wymagało zgody ich rodziców (opiekunów prawych). Będzie to miało miejsce, jeśli szkoła będzie chciała przetwarzać dane osobowe w szerszym zakresie, niż dopuszczają to przepisy prawa, oraz kiedy szkoła będzie chciała użyć wizerunku ucznia na stronie internetowej bądź na profilu społecznościowym albo użyć jego wizerunku na tablicy ogłoszeń szkoły²2.

Obowiązkiem dyrektora szkoły jest również zapewnienie bezpieczeństwa danych. W każdej szkole konieczne jest zastosowanie właściwych środków technicznych oraz organizacyjnych, które zapewnią ochronę przetwarzanych danych osobowych umożliwiających zidentyfikowanie konkretnej osoby (np. imię i nazwisko, adres zamieszkania, PESEL). Zastosowane środki muszą być odpowiednie do zagrożeń oraz kategorii danych objętych ochroną. Należy mieć na uwadze, aby zabezpieczyć dane przed ich udostępnieniem osobom nieupoważnionym, zabraniem, przetwarzaniem z naruszeniem Ustawy o ochronie danych osobowych oraz zmianą, utratą, uszkodzeniem lub zniszczeniem ${ }^{23}$. Do przetwarzania danych mogą być dopuszczone wyłącznie osoby mające upoważnienie nadane przez administratora danych (art. 37 Ustawy o ochronie danych osobowych). Dyrektor szkoły powinien mieć na względzie, aby upoważniana osoba podpisała oświadczenie o znajomości przepisów o ochronie danych osobowych oraz o zachowaniu w tajemnicy

19 Ustawa z dnia 7 września 1991 r. o systemie oświaty (Dz.U. z 2017 r., poz. 2198 z późn. zmianami).

20 Ustawa z dnia 15 kwietnia 2011 r. o systemie informacji oświatowej (Dz.U. z 2017 r., poz. 2159 z późn.zmianami).

${ }^{21}$ Ustawa z dnia 26 stycznia 1982 r. Karta Nauczyciela (Dz.U. z 2017 r., poz. 1189 z późn. zmianami).

${ }^{22}$ Generalny Inspektor Danych Osobowych, Twoje dane-Twoja sprawa, Obowiązki dyrektora szkoły z zakresu ochrony danych osobowych, https://men.gov.pl/wp-content/uploads/2017/04/poradnik-obowiazki-dyrektora-szkoly-z-zakresu-ochrony-danych-osobowych.pdf [dostęp: 25.01.2018].

${ }^{23}$ A. Chamczyńska-Penkala, Ł. Zegarek, Procedury i instrukcje związane z ochrona danych osobowych $w$ szkole, https://oficynamm.pl/oferta_elementy/do_pobrania/szkola/odows_artykul.pdf [dostęp: 25.01.2018]. 
informacji, do których ma dostęp. Ponadto dyrektor szkoły jest obowiązany zapewnić kontrolę nad tym, jakie dane osobowe, kiedy i przez kogo zostały wprowadzone do zbioru oraz komu są przekazywane (art. 38 Ustawy o ochronie danych osobowych). W piśmiennictwie przyjmuje się, że dyrektor może przeprowadzić kontrolę po to, aby sprawdzić, czy dane są odpowiednio zabezpieczone, oraz czy nie mają do nich dostępu osoby nieuprawnione ${ }^{24}$.

\section{Podsumowanie}

Powyższe rozważania wskazują, że dyrektor szkoły będący administratorem danych osobowych w szkole jest zobowiązany przestrzegać regulacji prawnych dotyczących ochrony danych osobowych w kierowanej przez siebie placówce. Istotne jest, że omawiane instytucje prawne muszą być stosowane przez wszystkie placówki oświatowe. Szkoła może przetwarzać dane osobowe, do których upoważniają ją wskazane przez autora w artykule akty prawne. Ponadto szkoła, chcąc wykorzystać wizerunek ucznia, musi uzyskać na to zgodę jego rodziców (opiekunów prawnych).

\section{BIBLIOGRAFIA}

\section{Akty prawne:}

Ustawa z dnia 2 kwietnia 1997 r. Konstytucja Rzeczypospolitej Polskiej (Dz. U. Nr 78 , poz. 483 z późn. zmianami).

Ustawa z dnia 26 stycznia 1982 r. Karta Nauczyciela (Dz.U. z 2017 r., poz. 1189 z późn. zmianami).

Ustawa z dnia 7 września 1991 r. o systemie oświaty (Dz.U. z 2017 r., poz. 2198 z późn. zmianami).

Ustawa $z$ dnia 4 lutego 1994 r. o prawie autorskim $i$ prawach pokrewnych (Dz.U. z 2017 r., poz. 880).

Dyrektywa 95/46/WE Parlamentu Europejskiego i Rady z dnia 24 października 1995 r. (Dz.U.UE.L.1995.281.31).

Ustawa z dnia 29 sierpnia 1997 r. o ochronie danych osobowych (Dz.U. z 2016 r., poz. $922 \mathrm{z}$ późn. zmianami).

Ustawa z dnia 15 kwietnia 2011 r. o systemie informacji oświatowej (Dz.U. z 2017 r., poz. 2159 z późn. zmianami).

${ }^{24}$ Tamże. 
Rozporzadzenie Parlamentu Europejskiego i Rady UE 2016/679 z dnia 27 kwietnia $2016 r$. w sprawie ochrony osób fizycznych $w$ związku z przetwarzaniem danych osobowych $i$ w sprawie swobodnego przeplywu takich danych oraz uchylenia dyrektywny 95/46/WE (ogólne rozporządzenie o ochronie danych) (Dz.U.UE.L.2016.119.1).

\section{Orzeczenia sądów:}

Wyrok Sądu Apelacyjnego w Warszawie z dnia 1 stycznia 2009 r. w sprawie o sygnaturze I Aca 22/09, Lex nr 1680164.

\section{Literatura:}

Barta J., Markiewicz R., Ustawa o prawie autorskim i prawach pokrewnych. Komentarz, wyd. V.

Barta J., Fajgielski P., Markiewicz R., Ochrona danych osobowych. Komentarz, wyd. VI, Warszawa 2015.

Flisiak D., Prawa autorskie i prawa pokrewne. Komentarz, Warszawa 2015.

Garlicki L., Zubik M., Konstytucja Rzeczypospolitej Polskiej. Komentarz, t. II, wyd. II, Warszawa 2016.

Szpunar M., Konektywizm - (r)ewolucja kształcenia w technologicznym świecie, „Horyzonty wychowania” 2015.

Wiewiórowski R., „Głos Nauczycielski”, 27.10.2010, nr 43.

\section{Strony internetowe:}

Chamczyńska-Penkala A., Zegarek Ł., Procedury i instrukcje zwiąane z ochrona danych osobowych $w$ szkole, https://oficynamm.pl/oferta_elementy/do_ pobrania/szkola/odows_artykul.pdf.

Generalny Inspektor Danych Osobowych, Twoje dane-Twoja sprawa, Obowiązki dyrektora szkoły z zakresu ochrony danych osobowych, https://men.gov. $\mathrm{pl} /$ wp-content/uploads/2017/04/poradnik-obowiazki-dyrektora-szkoly-z-zakresu-ochrony-danych-osobowych.pdf. 